\title{
Potential Output in a Rapidly Developing Economy: The Case of China and a Comparison with the United States and the European Union
}

\author{
Jinghai Zheng, Angang Hu, and Arne Bigsten
}

\begin{abstract}
The authors use a growth accounting framework to examine growth of the rapidly developing Chinese economy. Their findings support the view that, although feasible in the intermediate term, China's recent pattern of extensive growth is not sustainable in the long run. The authors believe that China will be able to sustain a growth rate of 8 to 9 percent for an extended period if it moves from extensive to intensive growth. They next compare potential growth in China with historical developments in the United States and the European Union. They discuss the differences in production structure and level of development across the three economies that may explain the countries' varied intermediate-term growth prospects. Finally, the authors provide an analysis of "green" gross domestic product and the role of natural resources in China's growth. (JEL L10, L96, O30)
\end{abstract}

Federal Reserve Bank of St. Louis Review, July/August 2009, 91(4), pp. 317-42.

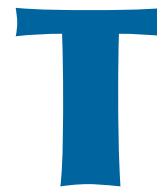

he rapid development of emerging markets is changing the landscape of the world economy and may have profound implications for international relations. China has often been regarded as the most influential emerging market economy. Projections indicate that the absolute size of the Chinese economy may be larger than that of the United States within two to three decades. While China's growth performance since reform has been hailed as an economic miracle (Lin, Cai, and Li, 1996), concerns over the sustainability of its growth pattern have emerged in recent years when measured total factor productivity (TFP) growth has slowed.
In recent years, economists have increasingly referred to China's growth pattern as "extensive." Extensive growth is intrinsically unsustainable because growth is generated mainly through an increase in the quantity of inputs rather than increased productivity. In a previous paper (Zheng, Bigsten, and $\mathrm{Hu}, 2009$ ), we focused on China's capital deepening versus TFP growth and private versus government initiatives. In this article, we first compare China's growth performance with what would otherwise have been feasible, taking into account the main factors commonly employed to generate growth in rapidly developing economies. In other words, we compare official statistics with estimates of "potential" output growth to shed further light on China's recent growth patterns.

Jinghai Zheng is a senior research fellow in the Department of International Economics at the Norwegian Institute of International Affairs, Norway, an associate professor in the department of economics at Gothenburg University, Sweden, and a guest research fellow at the Centre for China Studies, Tsinghua University, Beijing, China. Angang Hu is a professor at the School of Public Policy and Management at Tsinghua University. Arne Bigsten is a professor in the department of economics at Gothenburg University. The authors thank Justin Yifu Lin for his support and encouragement of this project and Xiaodong Zhu for useful discussion. The study was also presented at the Chinese Economic Association (Europe) Inaugural Ceremony, December 17, 2008, Oslo, Norway. The authors thank participants at the event and especially those who commented on their paper. The study benefited from research funding from the Center of Industrial Development and Environmental Governance at the School of Public Policy and Management, Tsinghua University. Yuning Gao provided excellent research assistance.

(c) 2009, The Federal Reserve Bank of St. Louis. The views expressed in this article are those of the author(s) and do not necessarily reflect the views of the Federal Reserve System, the Board of Governors, or the regional Federal Reserve Banks. Articles may be reprinted, reproduced, published, distributed, displayed, and transmitted in their entirety if copyright notice, author name(s), and full citation are included. Abstracts, synopses, and other derivative works may be made only with prior written permission of the Federal Reserve Bank of St. Louis. 
Second, we provide projections of the future potential of the Chinese economy and discuss China's impact on the world economy. Specifically, we compare potential growth in China with that for the United States and European Union (EU). We note that structural characteristics, rapid accumulation in capital stock, and improvement in labor quality are the major factors behind China's phenomenal economic growth. China's future TFP growth is likely to be faster than that of the United States and EU because of the stock of world knowledge it may easily access at affordable prices to enhance its production possibilities (Prescott, 2002).

Nobel laureate Ed Prescott (1998) asked why "growth miracles" are a recent phenomenon. We suspect that the main reasons are differences in production structure and in the level of development. Examples include the East Asian newly industrialized countries (NICs), to some extent post-WWII Japan and Germany, and the Soviet Union between the first and second World Wars and in the early years of the Cold War. Now, due to rapid industrialization, China will soon join the ranks of the high-performing East Asian nations. Understanding the causes and conditions of economic miracles may prove useful for developing countries. Understanding differences in production structure and the level of development may also help explain why productivity slowed in the United States and EU in the early 1970s, then started to surge in the United States but stagnated in Europe in the mid-1990s.

To analyze growth potential, we consider the usual suspects of demographics, rural-urban migration, and aging. In addition, we discuss how estimates of potential output have affected Chinese government policy regarding growth planning. Because environmental regulations and concerns are of increasing international importance, we assess in the final section of this analysis the influence of environmental factorsspecifically, to what extent past economic growth reflected environmental "inputs" not elsewhere accounted for.

\section{THE ANALYTICAL FRAMEWORK}

Years before the current worldwide credit crunch, the economics literature included many works that foresaw the looming economic crisis (e.g., Gordon, 2005; Phelps, 2004; Stiglitz, 2002; and Brenner, 2000 and 2004). Gordon's (2005) application of the growth accounting framework to the study of the U.S. productivity revival and slowdown stands out as convincing evidence that economic theory can powerfully inform empirical analysis for macroeconomic planning.

Since the publication of Solow's seminal work on technical progress and the aggregate production function, growth accounting has been used to assess the economic performance of the former Soviet Union (Ofer, 1987), raise concerns about the sustainability of the economies of the East Asian "tigers" (Hong Kong, South Korea, Singapore, and Taiwan) just a few years before the East Asian financial crisis (Young, 1995; Kim and Lau, 1994; and Krugman, 1994), and, recently, forewarn planners about the macroeconomic imbalances in China (Zheng and $\mathrm{Hu}, 2006$ ).

Adequately implemented and understood, growth accounting is a useful instrument for improving the analysis of growth potential for many countries and regions. Several examples in the literature show that growth accounting methods are sensitive enough to detect significant changes in productivity performance if production parameters are carefully chosen.

Growth accounting decomposes growth in output into its components:

$$
\frac{\dot{Y}}{Y}=\frac{\dot{A}}{A}+\alpha \frac{\dot{K}}{K}+(1-\alpha) \frac{\dot{L}}{L},
$$

where $Y$ is gross domestic product (GDP) and $\dot{Y}$ change in GDP over time; $K$ is capital stock and $\dot{K}$ the change in capital stock; labor is $L$ and $\dot{L}$ the change in labor input; TFP growth is $\dot{A} / A$; $0<\alpha<1$ is the output elasticity of capital; and (1 $-\alpha)$ is the output elasticity of labor.

Potential output growth may be calculated via equation (1) from knowledge of the potential growth of each of the right-hand side components, plus estimates of output elasticities for the various inputs. Obviously, both the growth potentials 
and the output elasticities will differ among countries, reflecting structural differences. Typical growth accounting structures are represented as follows: For China (Chow and Li, 2002; and Chow, 2008),

$$
\frac{\dot{Y}}{Y}=\frac{\dot{A}}{A}+0.6 \frac{\dot{K}}{K}+0.4 \frac{\dot{L}}{L}
$$

for the United States (Congressional Budget Office [CBO], 2001),

$$
\frac{\dot{Y}}{Y}=\frac{\dot{A}}{A}+0.3 \frac{\dot{K}}{K}+0.7 \frac{\dot{L}}{L} ;
$$

and for the EU (Mossu and Westermann, 2005), ${ }^{1}$

$$
\frac{\dot{Y}}{Y}=\frac{\dot{A}}{A}+0.4 \frac{\dot{K}}{K}+0.6 \frac{\dot{L}}{L} .
$$

China has an output elasticity of capital of 0.6 , compared with 0.3 for the United States. Differences of this magnitude are large enough to generate a significant difference between the growth potential of the two economies. For example, a capital stock growth rate of 10 percent would enable China to grow by at least 6 percent per year, whereas, all else constant, it would increase the U.S. growth rate by only 3 percent per year. Growth differences can also be related to differences in investment in physical capital as well as in TFP growth. For developing economies such as China, investment opportunities abound because of the country's relatively low level of development compared with that of the United States, EU, and other industrialized countries. For the same reason, China more easily absorbs and benefits from existing worldwide technology, whereas developed economies, especially the United States, have to rely on new knowledge and innovations to shift their production frontier.

\section{Steady-State and Sustainable Growth}

The growth accounting framework provides a compact formula for the study of potential output growth. We define "potential output" as the highest level of real GDP that can be sustained

1 Proietti, Musso, and Westermann (2007) set capital elasticity at 0.35 and labor elasticity at 0.65 . over the period of interest. Growth associated with potential output can therefore be termed "sustainable growth." We divide sustainable growth into three categories according to the different time frames considered.

The first concept of sustainable growth refers to circumstances in which certain measures of output growth are maintained permanently as time goes to infinity. The literature offers two different though related output measures that may be used in this context. Different studies have used them for different purposes. Sustainable growth can be defined as a growth pattern that generates sustained growth in per capita income over an infinite time horizon. Usually, per capita income is treated as a measure of living standards. Following Romer (2006), the standard Solow growth model can be expressed as follows:

$$
\begin{aligned}
& Y=F(K, L, A(t)), \quad \dot{A}(t) \geq 0, \\
& A(t)=e^{x t}, L(t)=e^{n t},
\end{aligned}
$$

where $Y$ is total output, $F(\cdot)$ is the production function, $K$ is capital input, $L$ is labor input, and $A(t)$ is the level of technology that progresses at the exponential rate $x$ while the labor force grows at the exponential rate $n$. The change in capital stock is given by

$$
\dot{K}=I-\delta K=s \cdot F(K, L, A(t))-\delta K,
$$

where $I$ is investment, $\delta$ the real depreciation rate, and $s$ the saving rate. For $I=s Y=s \cdot F(K, L, A(t))$, we have

$$
\dot{K}=s \cdot F(K, L, A(t))-\delta \cdot K .
$$

Dividing by labor input, $L$, on both sides of equation (7) yields

$$
\frac{1}{L} \frac{d K}{d t}=s \cdot F\left(\frac{K}{L}, A(t)\right)-\delta \frac{K}{L} .
$$

Because $k=K / L$, the growth rate of $k$ can be written as

(9) $\dot{k}=\frac{d(K / L)}{d t}=\frac{1}{L} \frac{d K}{d t}-\frac{K}{L^{2}} \frac{d L}{d t}=\frac{1}{L} \frac{d K}{d t}-\frac{K}{L} n$,

where $n=\frac{\Delta L}{L}$. 


\section{Zheng, Hu, Bigsten}

Rearrange equation (9):

$$
\frac{1}{L} \frac{d K}{d t}=\dot{k}+n k=s \cdot F(k, A(t))-\delta k ;
$$

combine equations (8) and (10):

$$
\dot{k}=s \cdot F(k, A(t))-(n+\delta) \cdot k ;
$$

then divide $k$ on both sides of the equation to get the growth rate of $k$ given by

$$
\gamma_{k}=s \cdot F(1, A(t) / k)-(n+\delta) .
$$

At steady state, $\gamma_{k}^{*}$ is constant, which requires that $s, n$, and $\delta$ are also constant. Thus the average product of capital, $F(k, A(t)) / k$, is constant in the steady state. Because of constant returns to scale, $F(1, A(t) / k)$ is therefore constant only if $k$ and $A(t)$ grow at the same rate; that is $\gamma_{k}^{*}=\mathrm{x}$. Output per capita is given by

$$
y=F(k, A(t))=k \cdot F(1, A(t) / k),
$$

and the steady-state growth rate of $y=x$. This implies that, in the long run, output per capita grows at the rate of technical progress, $x$. Note that this conclusion is conditioned on parameters of the model staying constant, including the saving rate and, hence, the rate of capital formation. This property of the model may explain why developing economies can grow faster, as exhibited by the growth miracles in the East Asian NICs, than developed economies because the potential for absorbing new technologies is larger in the former.

Another important implication of the Solow growth model is that less-advanced economies, such as China, will tend to have higher growth rates in per capita income than the more-advanced economies, such as the United States and EU, because there are more investment opportunities in developing nations. The World Bank (1997, p. 12) called this phenomenon "the advantages of the backwardness." This property is also referred to as "absolute convergence" when the analysis is not conditioned on other characteristics of the economies and "conditional convergence" when the analysis is only valid among economies with the same steady-state positions. However, caution should be exercised when applying this property of the model to real-world situations. The prop- erty demonstrates only what the supply side of the economy could achieve if other factors, such as demand conditions, efficiency of the economy, and political stability, are present.

\section{Extensive versus Intensive Growth}

Sustainable growth might as well be interpreted as growth of GDP only, which is particularly interesting if one is interested in the absolute size of the economy. It is the size of the aggregate economy that matters with regard to international influence in both economics and politics. Sustainable growth in this context means the rate of investment need not rise in order to maintain a given rate of GDP growth. Such sustainable growth is considered intensive growth. A borderline case for sustainable growth of this kind is when the capital stock growth rate equals the GDP growth rate.

Extensive growth refers to a growth strategy focused on increasing the quantities of inputs (Irmen, 2005). As capital accumulation and growth of the labor force raise the growth rate of aggregate output, because of diminishing returns these growth effects will not have a permanent effect on per capita income growth (Irmen, 2005). In contrast, intensive growth focuses on TFP. In our model, labor growth and TFP growth are exogenous; the only input with endogenous growth is capital. A key feature of the extensive growth model is that capital grows faster than GDP (or gross national product) because of the high growth rate of capital on the one hand and few productivity advancements on the other. Consequently, the share of investment in GDP, in constant prices, must grow continuously to sustain the growth rate of capital (Ofer, 1987). Specifically, the relation between $I$ (investment), $K$ (the capital stock), and $Y$ (national product) in real terms can be written as follows:

$$
I / K=(I / Y)(Y / K) .
$$

Notice that the growth accounting formula is given by $\dot{Y} / Y=\dot{A} / A+\alpha \dot{K} / K+\beta \dot{L} / L$, where (·) denotes growth rates, $L$ is labor, and $A$ is the level of technology. Given the growth rate in the labor input and the rate of technological progress, sustainable growth in $Y$ requires sustainable growth 
in $K$. Under intensive growth, $\dot{K} / K<\dot{Y} / Y$, so $Y / K$ rises over time. For $I / K(=\dot{K} / K)$ to stay constant, $I / Y$ must decline; that is, $\dot{I} / I<\dot{Y} / Y$. In other words, the gross capital formation rate does not have to rise to sustain a given growth rate in output, which is feasible.

Under extensive growth, $\dot{K} / K>\dot{Y} / Y$, so $Y / K$ declines and a constant $I / K$ implies a rising $I / Y$, which is not sustainable in the long run. Moreover, the share of investment in GNP in current prices may be written as $I_{C} / K_{C}=I P_{I} / Y P_{Y}$, where $C$ represents "in current prices" and $P$ the price level. A change in the relative price of $I$ (for example, due to faster technological change) may slow the rise of $I / Y$ in real terms.

If the initial capital stock growth rate is sufficiently low, the economy will grow for a sustained period of time even if capital stock growth exceeds GDP growth substantially. Examples are the Soviet economy in the 1950s and 1960s, the Japanese economy during about the same period, and later the East Asian NICs from the 1960s to 1980s. These economies all experienced rapid economic growth in a relatively short period of time. If the capital growth rate is too high, extensive growth may not be sustainable in the intermediate term or the long run. In some typical cases, sustainable growth requires that the saving rate (and hence the capital formation rate) vary only within a feasible range (say, between 0 to 50 percent) if borrowing is not allowed. Compared with sustainable growth in per capita income in the long run, this type of growth can be sustained only for a limited time because it relies on growth of transitional dynamics rather than on steady-state growth capabilities.

\section{Sustainable Growth with Input Constraints}

A third concept of sustainable/potential growth is related to sustainable growth in inputs, especially labor. Everything else equal, change in the labor input can be crucial for growth to be sustained. The economic history of many countries shows that demographics are important for rapid economic growth. In many developed countries, faster growth rates may not be sus- tained simply because labor is lacking. A country with a large population either too young or too old to work will have a lower growth rate than one with a large working-age population.

Following Musso and Westermann (2005), we decompose labor input into its components. Because we do not have hours worked as a measure of labor, we use employment. Employment, $E$, at time $t$ is defined as the difference between the labor force, $N$, and total unemployment, $U$, and can be expressed as a function of the unemployment rate, ur. The labor force is the product of the participation rate, $p r$, and the working-age population, $p^{W A}$. The working-age population is a function of total population, $P$, and the dependency ratio, $d r$, where the latter is defined as the ratio between the number of persons below 15 and above 64 years of age and the working-age population. These relationships are summarized as follows:

$$
\begin{aligned}
& E_{t} \equiv N_{t}-U_{t}=N_{t} \cdot\left(1-u r_{t}\right) \\
& N_{t} \equiv p r_{t} \cdot P_{t}^{W A} \\
& P_{t}^{W A} \equiv P_{t} \cdot \frac{1}{1+d r_{t}} .
\end{aligned}
$$

The potential GDP growth of China may be expressed as

$$
\begin{aligned}
& g_{Y}=g_{A}+\alpha(i-\delta)+(1-\alpha) \\
& \left(g_{h}-\frac{u r}{1-u r} g_{u r}+g_{p r}-\frac{d r}{1+d r} g_{d r}+g_{p}\right)
\end{aligned}
$$

where the variables are

$g_{Y}$, the growth rate of potential output, $Y$;

$g_{A}$, growth of total factor productivity, $A$;

$\alpha$, the output elasticity of capital;

$(1-\alpha)$, the output elasticity of labor;

$i$, the investment rate;

$\delta$, the depreciation rate;

$g_{h}$, growth in years of schooling, $h$;

$g_{u r}$, growth of the unemployment rate, ur;

$g_{p r}$, growth of the participation rate, pr;

$g_{d r}$, growth of the dependency ratio, $d r$; and,

$g_{p}$, the growth rate of the population, $p$. 


\section{A Comparison of the Three Concepts}

A comparison of the three concepts above can be derived from the Solow growth model, but each emphasizes a different aspect of the growth problem. Sustainable growth is derived according to the steady-state solution of the dynamic system. It refers to the mathematical long run, given that the saving rate, depreciation, and population growth are fixed. The variable of interest is the growth rate of per capita income and, hence, TFP growth. In this case, the Solow growth model predicts that low-income economies will grow faster than high-income economies, which leads to the concept of convergence.

The second concept, extensive versus intensive growth, concerns directly the GDP growth rate rather than per capita income. In this case, the saving rate is allowed to change. When the investment rate is so high that the saving rate must rise to, say, over 50 percent of GDP, then the growth pattern is considered problematic. Such growth is not sustainable, even in the intermediate term. However, the problem may arise slowly: If the capital stock growth rate is only 3 percent per year, it may take two or three decades for the saving rate to rise to 30 percent of GDP, even if the growth pattern was initially extensive. This is a major difference between rapidly developing and developed economies. The latter need not worry much about the intermediate term if growth in capital stock exceeds GDP growth, because growth rates are generally low in the relevant variables. In the long run, however, no extensive growth pattern is sustainable. This concept heightens the need to pay attention to the pattern of capital accumulation.

The third concept emphasizes the input constraints. Growth will be sustained only as long as sufficient inputs are available at a given point in time. This formulation is often used to separate the labor input into its components.

\section{EMPIRICAL RESULTS}

In this section, we present two sets of empirical results within the framework outlined previously. We first use data from 1978-2007 to update our growth accounting results from Zheng, Bigsten, and Hu (2009). The emphasis is the timeseries behavior of TFP growth. Based on our TFP estimates, we provide potential growth measures conditional on the given investment rate and factors related to labor input, including demographics and the labor participation rate. We then compare the estimated potential growth with official statistics.

The second set of results offers projections of future growth. The growth scenarios should not be seen as simple extrapolations based on historical data. In fact, our calibration exercise relies heavily on knowledge of the production structure of the Chinese economy and the concept of intensive growth.

\section{China's Growth Pattern and Potential}

China's development strategy in recent years has been successful in promoting rapid economic growth, but it also created a series of macroeconomic imbalances. The rapid growth has benefited China both economically and politically, but whether it can or will be sustained, and for how long, is uncertain. The growth has been generated mainly through the expansion of investment (extensive growth) and only marginally through increased productivity (intensive growth). Some economists fear that if corrective measures are not taken, per capita income will eventually cease to grow. Kuijs and Wang (2006) point out that, if China's current growth strategies are unchanged, the investment-to-GDP ratio would need to reach unprecedented levels in the next two decades in order to maintain GDP growth of 8 percent per year. Our estimates in Table 1 show that China's growth pattern has been extremely extensive, with capital stock growth exceeding GDP growth by 3.56 percent during 1995-2007.

Next, we use equation (16) to calculate a measure of potential growth during 1978-2007. Our measure is built from estimates of the potential growth of each of the main factors that contribute to sustainable growth, that is, the terms on the right-hand side of equation (16). The first term in equation (16), $g_{A}$, is the TFP growth rate. We use a growth rate of 3.3 percent for the period 1978-95 and 1.9 percent for $1995-2007$, as in 


\section{Figure 1}

\section{GDP Growth, 1978-2007}

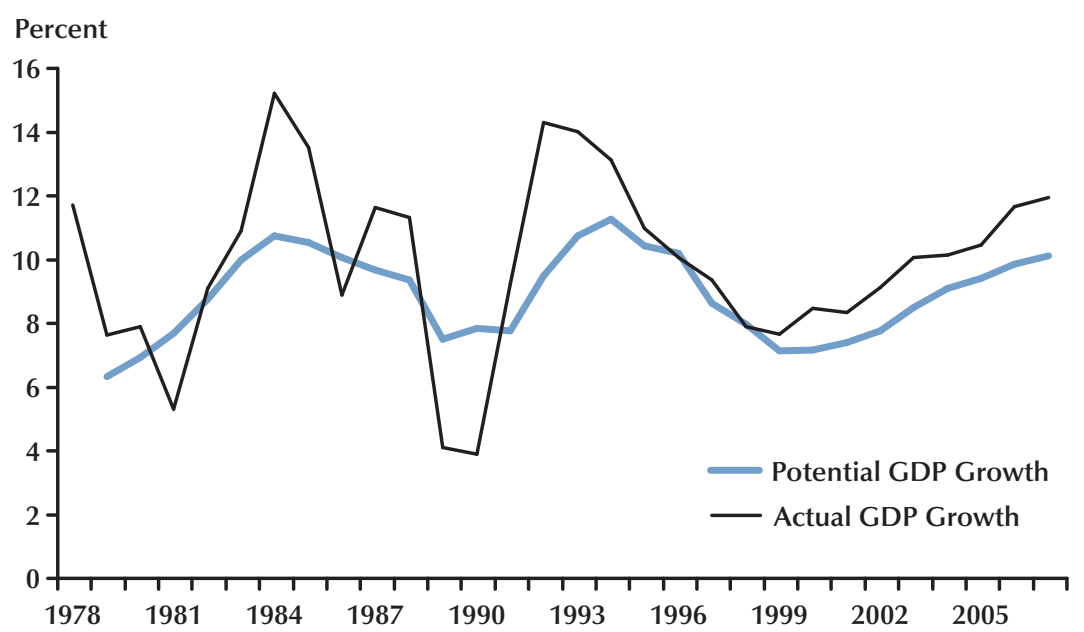

Zheng, Bigsten, and Hu (2009). The second term in equation (16) is the contribution of capital (equal to the investment rate minus the depreciation rate, multiplied by an output elasticity of capital of 0.5). The third term in equation (16) is the contribution of labor: the sum of the growth rates of hours worked per person, labor force participation, and population, minus the weighted growth rate of the unemployment rate and dependency ratio. We replace the growth of hours worked per person with the growth of quality-adjusted employment (multiplied by the average years of schooling). Figure 1 shows that, starting in 2002, actual GDP growth exceeded potential growth during six consecutive years. This result is consistent with the growth accounting result based on the realized production data in Table $1 .^{2}$

\section{Projections for the Medium Term}

Many projections for China's future output potential have appeared in recent years. We provide our own estimates using the analytical framework introduced earlier. We show that it is a valid concern that China's growth pattern as measured

2 "Green" GDP estimates and TFP trends will be discussed later in the paper.

\section{Table 1}

\section{Growth Accounting for China (percent)}

\begin{tabular}{lcc} 
Variable & $\mathbf{1 9 7 8 - 9 5}$ & $\mathbf{1 9 9 5 - 2 0 0 7}$ \\
\hline GDP & 10.11 & 9.25 \\
Capital stock & 9.12 & 12.81 \\
Quality-adjusted labor & 3.49 & 2.78 \\
TFP & 3.80 & 1.45
\end{tabular}

SOURCE: Updated to 2007 from Zheng, Bigsten, and Hu (2009), with an output elasticity of 0.5 .

by potential output may not be sustainable. The growth accounting result is striking when compared with what the government considers a sustainable growth target (8 percent for 2008).

Our projections rely heavily on two basic premises: (i) Capital stock growth cannot exceed GDP growth and (ii) a TFP growth rate of 2 to 3 percent must prevail for the foreseeable future. China's government was concerned about maintaining a GDP growth rate of 8 percent, both in the wake of the East Asian financial crisis of 1997 and when the Chinese economy started to overheat in 2003. We show how the "magic" 8 per- 
Table 2

\section{Sustainable Growth for the Chinese Economy}

\begin{tabular}{|c|c|c|c|c|c|c|}
\hline$\alpha$ & $g_{K}$ & $g_{L}$ & $g_{A}$ & $\alpha \mathbf{g}_{\boldsymbol{K}}$ & $(1-\alpha) g_{L}$ & $g_{Y}$ \\
\hline 0.5 & 11 & 3 & 3 & 5.5 & 1.5 & 10.0 \\
\hline 0.6 & 11 & 3 & 3 & 6.6 & 1.2 & 10.8 \\
\hline 0.5 & 11 & 3 & 2 & 5.5 & 1.5 & 9.0 \\
\hline 0.6 & 11 & 3 & 2 & 6.6 & 1.2 & 9.8 \\
\hline 0.5 & 10 & 3 & 3 & 5.0 & 1.5 & 9.5 \\
\hline 0.6 & 10 & 3 & 3 & 6.0 & 1.2 & 10.2 \\
\hline 0.5 & 10 & 3 & 2 & 5.0 & 1.5 & 8.5 \\
\hline 0.6 & 10 & 3 & 2 & 6.0 & 1.2 & 9.2 \\
\hline 0.5 & 9 & 3 & 3 & 4.5 & 1.5 & 9.0 \\
\hline 0.6 & 9 & 3 & 3 & 5.4 & 1.2 & 9.6 \\
\hline 0.5 & 9 & 3 & 2 & 4.5 & 1.5 & 8.0 \\
\hline 0.6 & 9 & 3 & 2 & 5.4 & 1.2 & 8.6 \\
\hline 0.5 & 8 & 3 & 3 & 4.0 & 1.5 & 8.5 \\
\hline 0.6 & 8 & 3 & 3 & 4.8 & 1.2 & 9.0 \\
\hline 0.5 & 8 & 3 & 2 & 4.0 & 1.5 & 7.5 \\
\hline 0.6 & 8 & 3 & 2 & 4.8 & 1.2 & 8.0 \\
\hline
\end{tabular}

cent growth rate can be derived from the growth accounting framework. Suppose that the borderline growth rate between extensive and intensive growth can be expressed as

$$
g_{Y}=\frac{g_{A}}{(1-\alpha)}+g_{L},
$$

which can be derived from the usual growth accounting formula assuming that the capital stock growth rate, $g_{K}$, equals the output growth rate, $g_{Y}$. In Table 2, the GDP growth rate, $g_{Y}$, is in the far-right-hand column; other columns show combinations of parameters consistent with $g_{Y}$. With a 3 percent TFP growth rate and 0.05 output elasticity of capital, the maximum sustainable output growth rate would be 9 percent. With a 2 percent TFP growth rate and 0.06 output elasticity of capital, the maximum sustainable output growth rate would be 8 percent, which is consistent with the Chinese government's growth target for 2008 (Wen, 2008).
The magical 8 percent growth rate also has interesting implications for the structural parameters of the production function. When the assumed output elasticity of capital is 0.6 , the corresponding sustainable growth rate is exactly 8 percent if TFP growth is 2 percent per year. However, 8 percent growth will not be sustainable if TFP growth is 2 percent per year but the output elasticity of capital is 0.5. Sustainable growth will be slightly more than 8 percent if TFP growth is 3 percent per year. Slower growth in the labor input (demographics) will reduce the projected output growth rate to some extent, but the trends will remain the same.

Economic growth in developing economies is considered to be mainly affected by three factors: rural-urban migration, demographics, and educational attainment. In the late 1990s, Chinese planners were preoccupied with maintaining a growth rate of 8 percent in the face of the East Asian financial crisis. Such forecasts relied on China's ability to maintain high capital forma- 
tion-but if the capital growth rate exceeds the GDP growth rate, the result is extensive growth, which is likely not sustainable in the longer run, as discussed above.

We offer one more example. For simplicity, we omit the role of human capital accumulation (see Zheng, Bigsten, and Hu, 2009). Assuming, say, the output elasticity of capital is 0.5 , the capital stock increases 8 percent per year, and the labor force grows slightly above 1 percent (as it has in the past decade), the TFP growth rate would be required to be 3.5 percent to achieve 8 percent GDP growth. Further, this would require the TFP contribution to GDP growth to reach 44 percent, which may be difficult to achieve in practice. Using this as a benchmark, the 5-year forecasts presented for China's 10th and 11th congressional sessions appear wildly overoptimistic because they require TFP growth to contribute 54 to 60 percent of GDP growth (see Zheng, Bigsten, and Hu, 2009).

\section{COMPARISONS WITH THE U.S. AND EU ECONOMIES}

In this section, given the structural differences, we calibrate the model to compare a typical scenario for the Chinese economy with the U.S. and EU economies. We demonstrate that growth potential varies across the three major economies because of differences in production structure, the level of development, and opportunities for absorbing foreign technologies. Growth in developed countries relies on mainly technological innovations because investment opportunities are far fewer than in developing countries. Because technology development often presents patterns of cyclical fluctuations, attempts to counterbalance business cycles or alter the trajectory of growth potentials may result in short-term gains but long-term losses. Understanding this is crucial for central banks to carry out sound monetary policies and to prevent future financial crises.

China clearly has benefitted from extensive growth in the intermediate term, but as previously shown this level of growth is not sustainable in the long run. However, China may still enjoy a high growth rate of 8 to 9 percent if it manages the transformation from extensive to intensive growth (see Table 2).

In his report to the First Session of the 11th National People's Congress in March 2008, Premier Wen Jiabao stated that "On the basis of improving the economic structure, productivity, energy efficiency and environmental protection, the GDP should grow by about eight percent" (Xinhua, 2008). This is the fourth consecutive year China set its GDP growth target at 8 percent (after five consecutive years of double-digit GDP growth) to emphasize the government's desire to promote both sound and fast economic and social development. ${ }^{3}$ Until recently, China has tightened monetary policy to curb inflation and an overheated property market to help the transition from extensive to intensive growth.

However, it appears that China's measures to cool its economy to a sustainable level were not well timed, considering recent developments in the world economy. By November 2008, most rich economies were facing recession. The U.S. economy has been in recession since December 2007 (as confirmed by the National Bureau of Economic Research in December 2008). In November 2008, the European economy officially fell into its first recession since the euro was introduced. In China, industrial production grew by only 8.2 percent from January through October 2008, less than half the pace of the previous year and its slowest for seven years. China announced a massive stimulus package ( $\$ 586$ billion) in early November 2008.

Although the stimulus package was intended to boost domestic demand and create more jobs, the World Bank pointed out that the stimulus policies provide China with a good opportunity to rebalance its economy in line with the objectives of the 11th Congress's five-year plan: "The stimulus package contains many elements that support China's overall long-term development and improve people's living standards. Some of the stimulus measures give some support to the rebalancing of the pattern of growth from invest-

\footnotetext{
3 China revised its GDP growth for 2007 from 11.9 percent to 13.0 percent and in that year overtook Germany to become the world's third-largest economy (Reuters, 2009). The growth figure was announced by the National Bureau of Statistics of China (NBSC) and was the fastest since 1993 (when GDP grew 13.5 percent).
} 
Table 3

Growth Projections (2009-30, percent)

\begin{tabular}{lcccc} 
Countries & Capital stock & Labor & TFP & GDP \\
\hline China & 8.0 & 3.0 & 2.5 & 8.0 \\
United States & 4.0 & 0.5 & 1.2 & 3.1 \\
EU & 3.0 & 0.0 & 1.0 & 2.2
\end{tabular}

NOTE: Output elasticity of both capital and labor is $\mathbf{0 . 5}$ for China, $\mathbf{0 . 4}$ for the EU, and 0.3 for the United States.

ment, exports, and industry to consumption and services. The government can use the opportunity of the fiscal stimulus package to take more rebalancing measures, including on energy and resource pricing; health, education, and the social safety net; financial sector reform; and institutional reforms" (World Bank, 2008, p. 1).

In the longer term, China will be able to maintain its momentum as a rapidly developing economy well into the next two decades or so while the United States and EU may manage a growth rate of only 2 to 3 percent (as calibrated in Table 3). ${ }^{4}$ Structural differences help explain the large differences in growth potential between China and the United States and EU. The contribution of capital in China is twice that in the United States. The level of development provides even greater opportunities for China than the United States and EU. Investment opportunities in China are nearly double those in the United States ${ }^{5}$; and the potential for China to absorb new technologies from developed nations is double that for the United States and EU.

Moreover, a shortage of labor (another important input to the production process) in developed economies will hinder faster growth of these economies in the intermediate term. In about 20

4 The growth rate in Table 3 is somewhat too optimistic for U.S. economists: "[M]ainstream economists are exceptionally united right now around the proposition that the trend growth rate of real gross domestic product (GDP) in the United States-the rate at which the unemployment rate neither rises nor falls is in the 2 percent to 2.5 percent range" (Blinder, 2002, p. 57).

5 Sterman (1985) presented a behavioral model of the economic long wave, which showed that "capital self-ordering" was sufficient to generate long waves. In Sterman (1983), capital self-ordering means that the capital-producing sector must order capital equipment such as large machinery to build up productive capacity. years China will face the same problem as its population ages. Demographic change due to China's baby boomers of the 1960s and 1970s entering retirement age may significantly affect the labor supply and the country's capacity to save and invest.

In the long run, economic prosperity depends on innovation-driven productivity growth. There is evidence, however, that worldwide innovations might have been ineffective in recent decades. The literature on diminishing technological opportunities since the early 1960s and recent studies on endogenous growth, which discuss related issues (see, e.g., Jones, 1999; Segerstrom, 1998; and Kortum, 1997), address this phenomenon. In a series of recent articles, Gordon (e.g., 2004) addresses the issue in terms of demand creation for new products and technological advances and suggests that the U.S. productivity revival that began in 1995 might not be sustainable (see Table 4). This suggests that the productivity slowdown that began in other developed countries in the early 1970s may continue into the next decade or so. Given the input constraints on potential output growth in the United States and EU, productivity is left as the only source of extra growth.

In this regard, historical lessons from the former Soviet Union need to be taken seriously. Soviet growth was spectacular: Its industrial

\footnotetext{
Investment expansions in the 1950s and 1960s accumulated large excess capacity in the United States and European Union. "But while stimulating basic research and training the labor force for 'new-wave' technologies are important, innovation alone will not be sufficient to lift the economy into a sustained recovery as long as excess capacity in basic industries continues to depress investment" (Sterman, 1983, p. 1276).
} 


\section{Table 4}

\section{Productivity Slowdowns in the Soviet Union, United States, and EU}

\begin{tabular}{|c|c|c|c|c|c|}
\hline Countries & Period & GDP & Capital & Labor & TFP \\
\hline \multirow[t]{2}{*}{ Soviet Union } & $1950-70$ & 5.4 & 8.8 & 1.8 & 1.6 \\
\hline & $1970-85$ & 2.7 & 7.0 & 1.1 & -0.4 \\
\hline \multirow[t]{3}{*}{ United States } & $1950-72$ & 3.9 & 2.6 & 1.4 & 1.6 \\
\hline & $1972-96$ & 3.3 & 3.1 & 1.7 & 0.6 \\
\hline & 1996-2004 & 3.6 & 2.6 & 0.7 & 1.5 \\
\hline \multirow[t]{2}{*}{ EU (euro zone) } & $1960-73$ & 5.1 & & 4.8 & 3.2 \\
\hline & 1973-2003 & 2.2 & 0.5 & 2.8 & 1.0 \\
\hline
\end{tabular}

SOURCE: Mostly period averages calculated from Ofer (1987) for the former Soviet Union, Gordon (2006) for the United States, and Musso and Westermann (2005) for the euro zone.

structure changed from an economy with an 82 percent rural population and a GNP produced mainly by agriculture to one with a 78 percent urban population and 40 to 45 percent of GNP originating in manufacturing and related industries (Ofer, 1987). This pattern of extensive growth lasted nearly 70 years, from the late 1920s to the mid-1980s. By 1970, Soviet TFP growth was zero and has been negative ever since (see Table 4). Although the current problem in Western countries is different because their patterns of growth have not been as extensive (for example, growth in capital stock has been 3 to 4 percent), their limited growth in TFP has been worrisome.

Limited TFP growth has important implications for macroeconomic planning. A straightforward strategy to boost productivity growth, of course, is to increase spending on research and development. Though many policymakers would like to believe that research and development for information and computer technologies (ICT) may benefit an economy in the long run, when managing the macroeconomy they need to consider the lag between the emergence of a new technology and the generation of sufficient demand. For example, the U.S. economy has recorded impressive productivity growth since the mid-1990s thanks to innovations and massive investments in ICT. But the ongoing financial crisis may dramatically alter the interpretation of the U.S. productivity boom of the past decade. Some critics suggest that the problem lies in the desire to maintain growth above what is sustainable by encouraging excessive investment in technology and loosening regulations for risky innovations in the financial sector. As far as macroeconomic planning is concerned, this amounts to taking the concept of "potential output" seriously. ${ }^{6}$

\section{ENVIRONMENTAL CONSTRAINTS}

The environment is a constraint on growth in China. Increased environmental awareness at both the central government and grassroots levels will put greater pressure on regional authorities to seek alternative patterns of growth. In Zheng, Bigsten, and $\mathrm{Hu}$ (2009) we note

The Chinese government has been working on criteria and indexes of a green GDP, which deducts the cost of environmental damage and resources consumption from the traditional gross domestic product (People's Daily,

6 Krugman (1997) notes that standard economic analysis suggests that the United States should not expect its economy to grow at much more than 2 percent over the next few years. He notes further that if the Federal Reserve tries to force faster growth by keeping interest rates low, serious inflation could result. Of course, inflation did not rise until recently, but the U.S. economy already started overheating in the mid-1990s. Jorgenson, Ho, and Stiroh (2006) project the best-case scenario for U.S. GDP growth to be 2.97 percent per annum for 2005-15, with an uncertainty range of 1.9 to 3.5 percent. McNamee and Magnusson (1996) give a detailed discussion on why a long-run growth rate of 2 percent could be a problem for the U.S. economy as a whole. 
March 12, 2004). Preliminary results in the recently issued Green GDP Accounting Study Report (2004) suggest that economic losses due to environmental pollution reached 512 billion yuan, corresponding to $3.05 \%$ of GDP in 2004, while the imputed treatment cost is 287 billion yuan, corresponding to $1.80 \%$ of GDP (The Central People's Government of the People's Republic of China, 2006). Although the concept of and measurement for green GDP are rather controversial, the report may serve as a wakeup call to the government's strategy of growth at all costs.

From a productivity analysis perspective, the concept of green GDP can be straightforwardly extended to TFP, that is, green TFP. A slower green TFP growth may imply a slower (green) GDP growth. (p. 881)

We demonstrate that although the green GDP level has increased as environmental factors have been taken into account, "green TFP" growth reveals a similar trend, as shown in the main text of this article.

\section{Environmental Factors}

The World Bank (1997) first proposed the concept and calculation of "genuine domestic savings," that is, a country's saving rate calculated after subtracting from total output the costs of depletion of natural resources (especially the nonreproducible resources) and environmental pollution.

A formal model of the genuine savings rate is given by Hamilton and Clemens (1999):

$$
G=G N P-C-\delta K-n(R-g)-\sigma(e-d)+m .
$$

Here, GNP-C is traditional gross savings, which includes foreign savings, where GNP is gross national product and $C$ is consumption; $G N P-C-\delta K$ is traditional net savings, where $\delta K$ is the depreciation rate of produced assets; $-n(R-g)$ is resource depletion; $S=-(R-g)$ is resource stocks, $S$, that grow by an amount $g$, are depleted by extraction $R$, and are assumed to be costless to produce; $n$ is the net marginal resource rental rate; $-\sigma(e-d)$ is pollution emission costs; $X=$ $-(e-d)$ is the growth of pollutants accumulated into a pollution stock, $X$, where $d$ is the quantity of natural dissipation of the pollution stock; $\delta$ is the marginal social cost of pollution; and $m$ is investment in human capital (current education expenditures), which does not depreciate (and may be considered as a form of disembodied knowledge).

Natural resource depletion is measured by the rent of exploiting and procuring natural resources. The rent is the difference between the producing price received by producers (measured by the international price) and total production costs, including the depreciation of fixed capital and return of capital.

Rational exploitation of natural resources is necessary for economic growth; however, if resource rents are too low, overexploitation may result. If the resources rents are not reinvested (e.g., in human resources) but instead used for consumption, the exploitation is also "irrational."

Pollution loss mostly refers to harm caused by $\mathrm{CO}_{2}$ pollution. It is calculated by the global margin loss caused by one ton of $\mathrm{CO}_{2}$ emissions, which Fankhauser (1995) suggests is US\$20.

We expand the green GDP measure from the World Bank to include not only natural capital lost (negative factor) and education expenditure (positive factor), ${ }^{7}$ but also net imports of primary goods (positive factor) and sanitation expenditure (positive factor). We calculate three different versions of GDP from 1978 to 2004: real GDP, World Bank-adjusted green GDP, and our author-adjusted green GDP (Table 5).

\section{Green Capital}

In the measurement of productivity, the different measures of capital formation greatly influence the measured capital stock constructed with the perpetual inventory method. We can define the green capital stock as following the method of Hamilton, Ruta, and Tajibaeva (2005):

$$
K_{i t}^{\prime}=K_{i t-1}^{\prime}\left(1-\delta_{i t}\right)+I^{\prime},
$$

where $\delta_{i t}$ is the depreciation rate. (Time subscripts are omitted.) Our depreciation rate increases

\footnotetext{
7 We use total education expenditures from NBSC (2006) instead of the education expenditures from World Development Indicators (2006).
} 
Figure 2

\section{Capital Formation as a Percentage of GDP}

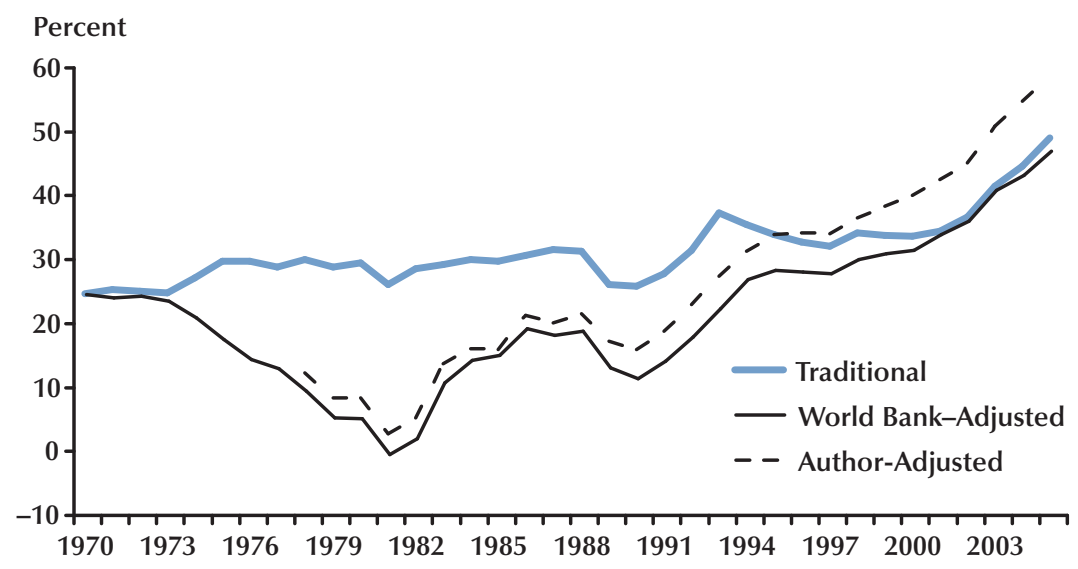

SOURCE: NBSC (2007a) and World Bank (2006).

\section{Figure 3}

\section{Capital Stock, 1978-2005}

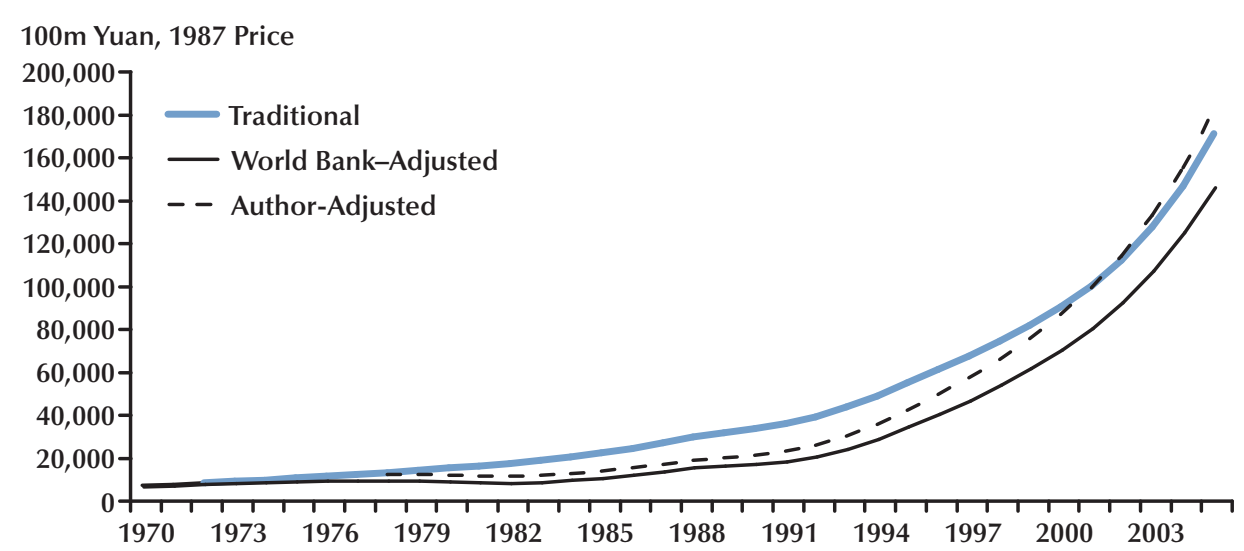

SOURCE: NBSC (2007a) and World Bank (2006). 
Table 5

Different Measures of Green GDP (percent of real GDP)

\begin{tabular}{|c|c|c|c|c|c|c|c|c|}
\hline Year & Real GDP & $\begin{array}{c}\text { Natural } \\
\text { capital lost }\end{array}$ & $\begin{array}{c}\text { Education } \\
\text { expenditure }\end{array}$ & $\begin{array}{l}\text { World Bank- } \\
\text { adjusted } \\
\text { green GDP }\end{array}$ & $\begin{array}{c}\text { Total } \\
\text { expense on } \\
\text { education }\end{array}$ & $\begin{array}{c}\text { Total } \\
\text { expense on } \\
\text { sanitation }\end{array}$ & $\begin{array}{l}\text { Net import } \\
\text { of primary } \\
\text { goods }\end{array}$ & $\begin{array}{c}\text { Author- } \\
\text { adjusted } \\
\text { green GDP }\end{array}$ \\
\hline 1978 & 100 & -23.01 & 1.85 & 78.84 & 2.10 & 3.10 & -0.73 & 81.46 \\
\hline 1979 & 100 & -26.52 & 1.84 & 75.33 & 2.31 & 3.20 & -0.77 & 78.22 \\
\hline 1980 & 100 & -27.54 & 2.08 & 74.54 & 2.51 & 3.30 & -0.71 & 77.56 \\
\hline 1981 & 100 & -29.91 & 2.11 & 72.20 & 2.51 & 3.40 & -0.77 & 75.23 \\
\hline 1982 & 100 & -28.48 & 2.19 & 73.70 & 2.59 & 3.50 & -0.86 & 76.75 \\
\hline 1983 & 100 & -19.92 & 2.16 & 82.24 & 2.61 & 3.60 & -1.27 & 85.02 \\
\hline 1984 & 100 & -17.35 & 2.07 & 84.72 & 2.51 & 3.30 & -2.18 & 86.28 \\
\hline 1985 & 100 & -16.96 & 2.05 & 85.09 & 2.51 & 3.00 & -2.80 & 85.75 \\
\hline 1986 & 100 & -12.76 & 2.10 & 89.34 & 2.62 & 3.10 & -1.90 & 91.06 \\
\hline 1987 & 100 & -14.41 & 1.90 & 87.49 & 2.31 & 3.20 & -1.97 & 89.13 \\
\hline 1988 & 100 & -13.57 & 1.87 & 88.30 & 2.22 & 3.30 & -1.08 & 90.87 \\
\hline 1989 & 100 & -13.74 & 1.87 & 88.13 & 3.07 & 3.40 & -0.74 & 91.99 \\
\hline 1990 & 100 & -15.26 & 1.79 & 86.53 & 3.56 & 4.03 & -1.56 & 90.77 \\
\hline 1991 & 100 & -13.93 & 1.79 & 87.86 & 3.38 & 4.11 & -1.31 & 92.25 \\
\hline 1992 & 100 & -12.50 & 1.70 & 89.20 & 3.25 & 4.09 & -0.78 & 94.06 \\
\hline 1993 & 100 & -10.88 & 1.71 & 90.82 & 3.00 & 3.96 & -0.40 & 95.68 \\
\hline 1994 & 100 & -8.07 & 2.14 & 94.07 & 3.09 & 3.78 & -0.58 & 98.22 \\
\hline 1995 & 100 & -7.57 & 1.97 & 94.40 & 3.09 & 3.86 & 0.40 & 99.78 \\
\hline 1996 & 100 & -7.27 & 2.01 & 94.74 & 3.18 & 4.21 & 0.41 & 100.53 \\
\hline 1997 & 100 & -5.89 & 2.01 & 96.12 & 3.21 & 4.29 & 0.49 & 102.10 \\
\hline 1998 & 100 & -3.98 & 1.97 & 97.99 & 3.49 & 4.47 & 0.24 & 104.22 \\
\hline 1999 & 100 & -3.43 & 1.94 & 98.51 & 3.73 & 4.66 & 0.64 & 105.60 \\
\hline 2000 & 100 & -4.87 & 1.95 & 97.07 & 3.88 & 4.62 & 1.78 & 105.41 \\
\hline 2001 & 100 & -4.07 & 1.94 & 97.88 & 4.23 & 4.58 & 1.46 & 106.20 \\
\hline 2002 & 100 & -4.03 & 1.95 & 97.92 & 4.55 & 4.81 & 1.43 & 106.76 \\
\hline 2003 & 100 & -4.30 & 1.96 & 97.66 & 4.57 & 4.85 & 2.31 & 107.43 \\
\hline 2004 & 100 & -4.58 & 1.97 & 97.39 & 4.53 & 4.75 & 3.97 & 108.67 \\
\hline
\end{tabular}

NOTE: World Bank-adjusted green GDP is the sum of columns 2, 3, and 4; the author-adjusted green GDP is the sum of columns 2, 3, 6,7 , and 8 .

SOURCE: World Bank (2006) and NBSC (2006). 


\section{Table 6}

\section{GDP, Green GDP, and TFP Growth, 1978-2004 (percent)}

\begin{tabular}{|c|c|c|c|c|c|c|}
\hline \multirow{2}{*}{$\frac{\text { Variable }}{G D P}$} & \multicolumn{2}{|c|}{ 1978-92 } & \multicolumn{2}{|c|}{ 1992-2004 } & \multicolumn{2}{|c|}{ 1978-2004 } \\
\hline & 9.02 & (100.0) & 10.12 & $(100.0)$ & 9.61 & (100.0) \\
\hline K & 7.74 & (34.3) & 11.27 & $(44.5)$ & 9.56 & (39.8) \\
\hline$L$ & 2.96 & (9.8) & 1.07 & (3.2) & 2.44 & (7.6) \\
\hline$H$ & 2.25 & (7.5) & 1.90 & (5.6) & 2.02 & (6.3) \\
\hline TFP1 & 4.36 & $(48.3)$ & 4.72 & $(46.6)$ & 4.45 & (46.3) \\
\hline GGDP1 & 9.87 & (100.0) & 11.06 & $(100.0)$ & 10.51 & (100.0) \\
\hline$K^{\prime}$ & 5.95 & $(24.1)$ & 15.88 & (57.4) & 10.42 & (39.7) \\
\hline$L$ & 2.96 & $(9.0)$ & 1.07 & (2.9) & 2.44 & (7.0) \\
\hline$H$ & 2.25 & (6.8) & 1.90 & (5.2) & 2.02 & (5.8) \\
\hline$T F P 2^{\prime}$ & 5.93 & $(60.1)$ & 3.82 & (34.5) & 5.00 & (47.6) \\
\hline GGDP2 & 10.47 & (100.0) & 10.75 & (100.0) & 10.60 & (100.0) \\
\hline$K^{\prime \prime}$ & 5.80 & (22.2) & 15.97 & (59.4) & 10.37 & (39.1) \\
\hline$L$ & 2.96 & (8.5) & 1.07 & (3.0) & 2.44 & (6.9) \\
\hline$H$ & 2.25 & (6.4) & 1.90 & (5.3) & 2.02 & (5.7) \\
\hline TFP3" & 6.59 & (62.9) & 3.47 & (32.3) & 5.11 & (48.2) \\
\hline
\end{tabular}

NOTE: GDP here is real GDP in 1978 prices; GGDP1 is the World Bank-adjusted green GDP; GGDP2 is the author-adjusted green GDP. $K$ denotes capital services input, $L$ labor input, $H$ denotes inputs of education, sanitation expenditure, and imports of primary goods.

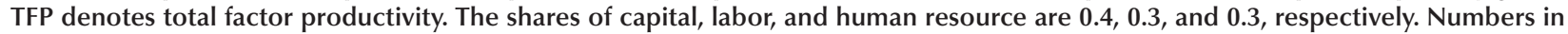
parentheses are the contribution ratio of each factor.

along a linear trend from 4 percent in 1952 to 6 percent in 2004. $I^{\prime}$ is the green fixed capital formation. In Figure 3, the World Bank analysis (Hamilton and Clemens, 1999) measures the green investment in any geographic or political area as

$$
I_{i t}^{\prime}=I_{i t}-n_{i t}\left(R_{i t}-g_{i t}\right)-\sigma_{i t}\left(e_{i t}-d_{i t}\right)+m_{i t},
$$

where $I$ is the traditional investment, $n_{i t}\left(R_{i t}-g_{i t}\right)-$ $\sigma_{i t}\left(e_{i t}-d_{i t}\right)$ is the natural capital lost, and $m_{i}$ is the education expenditure.

In this article, the author-adjusted green capital stock, $K^{\prime \prime}$, measures green investment as

$$
\begin{aligned}
& I_{i t}^{\prime \prime}=I_{i t}-n_{i t}\left(R_{i t}-g_{i t}\right) \\
& -\sigma_{i t}\left(e_{i t}-d_{i t}\right)+m_{i t}+n_{i t}+r_{i t},
\end{aligned}
$$

where $m_{i t}$ is total education expenditure (from NBSC), $n_{i t}$ is sanitation expenditure, and $r_{i t}$ is net import of primary goods.

\section{Green TFP}

As shown in Table 6, compared with traditional GDP, the two adjusted green GDPs (the World Bank and authors' measures) have about 0.5 to 0.6 percent higher average TFP growth rates in the 1978-2004 period, with lower TFP growth in the 1992-2004 period (the author-adjusted GDP is the lowest) than in the 1978-92 period. The TFP growth rate of traditional GDP is more stable and has the opposite trend.

As shown in Figure 4, the annual TFP growth rates of the adjusted green GDPs are higher than traditional GDP in most years before 1992. They reached 13 percent higher in 1983 and then began to fall, roughly maintaining a gap of 1 to 2 percentage points with traditional GDP through 2004. In 2004, the green GDPs reached their lowest growth rate, -4 percent.

Our analysis finds that China's growth has varied between episodes of extensive and inten- 


\section{Figure 4}

\section{TFP Growth, 1979-2005}

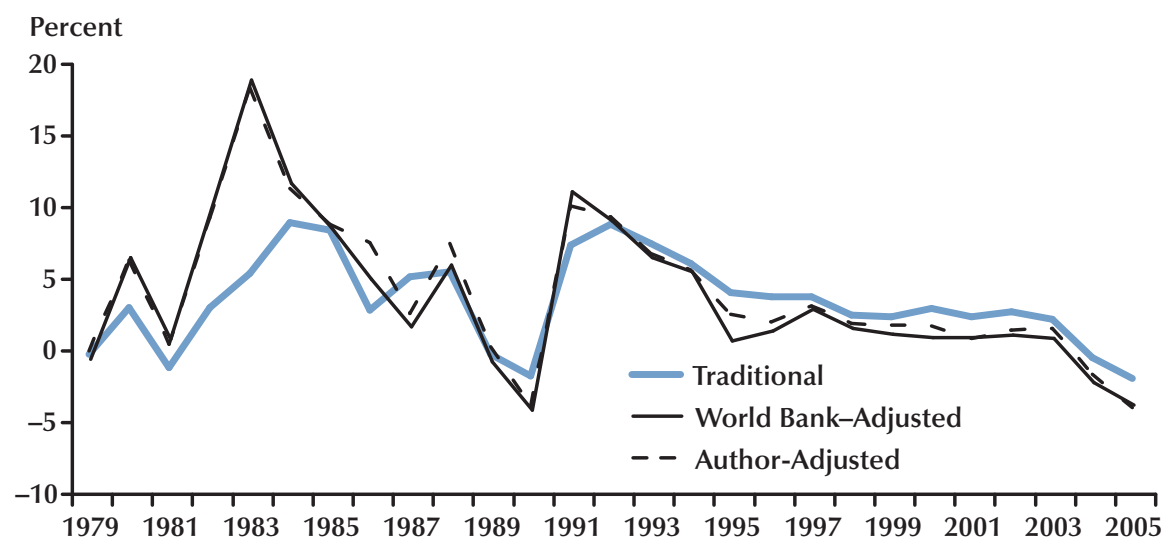

NOTE: This accounting does not include human capital. The share of capital and labor comes from Bai, Hsieh, and Qian's (2006) estimation.

sive growth. Economic growth in the 1980s was intensive growth-higher TFP growth compensated for the diminishing contribution of natural resources, that is, of "natural capital." During the 1990s, as a result of the comparative decline of its natural resource consumption, China's capital stock began to increase rapidly and its growth became more extensive, especially with respect to capital.

\section{CONCLUSION}

In this study, we have updated our previously published results on China's growth pattern, estimated China's potential output growth using official Chinese statistics, and compared China's medium-term growth perspectives with those for the United States and EU. Our findings suggest that China's extensive growth pattern might be sustainable in the intermediate term but not in the long run. However, China may still sustain a high growth rate of 8 to 9 percent if it manages the transformation from extensive to intensive growth. Several factors explain this possibility. Compared with the United States and EU, China is in a more favorable position with regard to (i) production structure, (ii) the potential to absorb new technologies, and (iii) investment opportunities. Perhaps these three factors largely explain Ed Prescott's query (1998) as to why economic "miracles" have been only a recent phenomenon.

China's reform policy since 1978 has dramatically increased its GDP as well as its role in the world economy. China was a marginal economy in 1978, but by 2007 its share of world GDP reached 5.99 percent at regular exchange rates (or 10.83 percent at purchasing power parity rates) (International Monetary Fund, 2008). This means that China now has the same economic weight as, for example, Germany. Because of China's rapid growth in recent years, its contribution to world growth has been substantial. In 2007 it was about 17 percent at regular exchange rates and as much as 33 percent at purchasing power parity rates. Even at regular exchange rates, China's contribution to global growth was considerably larger than that of the United States or EU. The global slowdown and financial contagion has now reduced the growth rate in China. Still, we believe China can continue to grow at a high rate over an extended period of time, which suggests that it will continue to be an important driver of world growth. 
China's importance in the global markets for goods and services also has increased considerably. In 1978, China contributed 0.6 percent of world exports, but by 2006 its share was over 7 percent (World Bank, 2008). This is an amazingly fast expansion and entry into the global market.

The export boom China experienced during the years before the world financial crisis of 2008 could not have continued at its rapid pace even in the absence of a worldwide economic slowdown. China's rapid growth has been driven by U.S. expansionary policy, China's acceptance into the World Trade Organization, the shift of assembly plants from other countries to China, and the undervaluation of China's currency, the yuan. The impact of these factors, however, cannot be sustained. Export growth was further supported by shifting the production structure toward the international market. However, with exports approaching half of GDP, there will be less scope for further shifts. In the future it is likely that export growth will more or less keep pace with GDP growth. As long as China continues to grow faster than the world average, it will increase its global market share. China's current strategy is to shift its production toward more-sophisticated goods and, even if the impact of such is as yet limited, it is very likely that trend will continue. This means that in the future we will likely see more and more intra-industry trade between China and the Organisation for Economic Co-operation and Development (OECD).

In the short term, the world is facing an extreme international financial crisis. Debate about China's role in this crisis is intense. International financial markets are clearly more integrated than in earlier crises, although China has not opened its capital account yet. With the rapid and extended global economic growth, economic imbalances have emerged, particularly between the United States and China. The United States has been undersaving and China has been oversaving. A key issue is the character and speed of the rebalancing process. In the United States, to build savings, consumption needs to increase at a slower pace than incomes, which could hinder growth for several years. How much China can counteract this by stimulating domestic demand remains to be seen, but steps in this direction have been taken. China has implemented a large fiscal expansion. The focus of policy reforms in the near future will probably be on domestic issues, and macroeconomic policy interventions will likely seek to stimulate local demand. The process of adjustment will take a long time, however, unless there is concerted policy action.

Another important issue is how international negotiations about the future design of the financial system will evolve, particularly because of the conflict between national sovereignty and the needs of global capital markets. Still, future discussions will have to involve China in a substantial way.

China is also expanding its economic operations abroad by aggressively using its sovereign wealth to acquire assets. It currently has extensive resources, whereas other global investors are facing problems. So the current crisis is an opportunity for China to invest abroad on a larger scale than ever before. As much as 75 percent of China's investments are in developed countries to develop marketing channels, access more advanced technology, and earn a good return on its capital. There is a risk, though, that China may overpay in its eagerness to acquire assets.

China enters the current crisis better prepared than it was when hit by the 1997 East Asian financial crisis. Still, even if China today is one of the most resilient economies in the world, it may not be able to have a very large impact on the Western economies. It buys many inputs from Asia, assembles goods at home, and then sells final goods to the OECD. This means that it will suffer during a recession in wealthier countries. The export markets have also been hurt by the disruptions in the trade credit market. Most intra-Asian trade is for intermediates that are assembled in China and then exported. Few Asian exports are for Chinese demand. Thus, other Asian countries suffer when China cannot export final goods to the OECD. Countries that can supply the Chinese domestic market may be able to benefit from Chinese development, though.

Overall it is likely that China will continue to grow and increase its market share and control of wealth, which in turn will increase its economic and political influence over the longer term. 


\section{Zheng, Hu, Bigsten}

\section{REFERENCES}

Bai, Chon-gen; Hsieh, Chang-tai and Qian, Yingyi. "The Return to Capital in China." NBER Working Paper No. 12755, National Bureau of Economic Research, December 2006; www.nber.org/papers/w12755.pdf?new_window=1.

Baker, Dean. "The New Economy Does Not Lurk in the Statistical Discrepancy." Challenge, July-August 1998a, 41(4), pp. 5-13.

Baker, Dean. "The Computer-Driven Productivity Boom." Challenge, November-December 1998b, 41(6), pp. 5-8.

Baker, Dean. "The Supply-Side Effect of a Stock Market Crash." Challenge, September-October 2000, 43(5), pp. 107-17.

Baker, Dean. "Is the New Economy Wearing Out?" Challenge, January-February 2002, 45(1), pp. 117-21.

Blinder, Alan S. "The Speed Limit: Fact and Fancy in the Growth Debate." American Prospect, September-October 1997, Issue 34, pp. 57-62.

Bosworth, Barry P. and Triplett, Jack E. "The Early 21st Century Productivity Expansion Is Still in Services." International Productivity Monitor, Spring 2007, Issue 14, pp. 3-19.

Brenner, Robert. "The Boom and the Bubble." New Left Review, November-December 2000, 6, pp. 5-39.

Brenner, Robert. "New Boom or New Bubble?" New Left Review, January-February 2004, 25, pp. 57-100.

Central People's Government of the People's Republic of China. Green GDP Accounting Study Report 2004. September 11, 2006; www.gov.cn/english/ 2006-09/11/content_384596.htm.

China Cement. "Discussion of Financing Mode for Improving the Energy Efficiency of China's Cement Industry" (in Chinese). 2007.

Chow, Gregory C. "Another Look at the Rate of Increase in TFP in China." Journal of Chinese Economic and Business Studies, May 2008, 6(2), pp. 219-24.
Chow, Gregory C. and Li, Kui-Wai. "China’s Economic Growth: 1952-2010." Economic Development and Cultural Change, October 2002, 51(1), pp. 247-56.

Congressional Budget Office. "CBO's Method for Estimating Potential Output: An Update." August 2001; www.cbo.gov/ftpdocs/30xx/doc3020/ PotentialOutput.pdf.

Congressional Budget Office. "R\&D and Productivity Growth: A Background Paper.” June 2005.

Fankhauser, Samuel. Valuing Climate Change: The Economics of the Greenhouse. London: Earthscan, 1995.

Gordon, Robert J. "Does the New Economy Measure Up to the Great Inventions of the Past?" Journal of Economic Perspectives, Fall 2000, 14(4), pp. 49-74.

Gordon, Robert J. "Hi-tech Innovation and Productivity Growth: Does Supply Create Its Own Demand?" NBER Working Paper No. 9437, National Bureau of Economic Research, January 2003;

www.nber.org/papers/w9437.pdf?new_window=1.

Gordon, Robert J. "Five Puzzles in the Behaviour of Productivity, Investment and Innovation." CEPR Discussion Paper No. 4414, Centre for Economic and Policy Research, June 2004.

Gordon, Robert J. "The 1920s and the 1990s in Mutual Reflection.” NBER Working Paper No. W11778, National Bureau of Economic Research, November 2005; www.nber.org/papers/w11778.pdf?new_ window $=1$.

Gordon, Robert J. "Future U.S. Productivity Growth: Looking Ahead by Looking Back." Presented at the Workshop at the Occasion of Angus Maddison's 80th Birthday, World Economic Performance: Past, Present, and Future. University of Groningen, The Netherlands, October 27, 2006.

Hamilton, Kirk and Clemens, Michael. "Genuine Savings Rates in Developing Countries." Environment Department, World Bank, 1998.

Hamilton, Kirk; Ruta, Giovanni and Tajibaeva, Liaila. "Capital Accumulation and Resource Depletion: 
A Hartwick Rule Counterfactual.” Policy Research Working Paper 3480, World Bank, January 2005.

Holz, Carsten A. “The Quantity and Quality of Labor in China 1978-2000-2025.” Working Paper, Hong Kong University of Science and Technology, May 2005; http://ihome.ust.hk/ socholz/Labor/HolzLabor-quantity-quality-2July05-web.pdf.

International Monetary Fund. World Economic Outlook: Financial Stress, Downturns, and Recoveries. Washington, DC: IMF, October 2008.

Irmen, Andreas. "Extensive and Intensive Growth in a Neoclassical Framework." Journal of Economic Dynamics and Control, August 2005, 29(8), pp. 1427-48.

Jones, Charles I. "Growth: With or Without Scale Effects?” American Economic Review, May 1999, 89(2), pp. 139-44.

Jorgenson, Dale W.; Ho, Mun S.; Samuels, Jon D. and Stiroh, Kevin J. "Industry Origins of the American Productivity Resurgence.” Economic Systems Research, September 2007, 19(3), pp. 229-52.

Jorgenson, Dale W.; Ho, Mun S. and Stiroh, Kevin J. "Potential Growth of the U.S. Economy: Will the Productivity Resurgence Continue?" Business Economics, January 2006, 41(1), pp. 7-16.

Kim, Jong-Il and Lau, Lawrence J. "The Sources of Economic Growth of the East Asian Newly Industrialized Countries." Journal of the Japanese and International Economies, September 1994, 8(3), pp. 235-71.

Kortum, Samuel S. "Research, Patenting, and Technological Change.” Econometrica, November 1997, 65(6), pp. 1389-419.

Krugman, Paul. "The Myth of Asia’s Miracle.” Foreign Affairs, November-December 1994, 73(6), pp. 62-78.

Krugman, Paul. "How Fast Can the U.S. Economy Grow?” Harvard Business Review, July-August 1997, 75(4), pp. 123-29.
Kuijs, Louis and Wang, Tao. “China’s Pattern of Growth: Moving to Sustainability and Reducing Inequality." China and World Economy, JanuaryFebruary 2006, 14(1), pp. 1-14.

Lin, Justin Yifu; Cai, Fang and Li, Zhou. The China Miracle: Development Strategy and Economic Reform. Hong Kong: Chinese University Press, 1996.

McNamee, Mike and Magnusson, Paul. "Let's Get Growing: The Economy Can Run Faster. Here's How To Make It Happen.” Business Week, July 8, 1996, p. 90-98.

Musso, Alberto and Westermann, Thomas. "Assessing Potential Output Growth in the Euro Area: A Growth Accounting Perspective.” ECB Occasional Paper No. 22, European Central Bank, January 2005; www.ecb.int/pub/pdf/scpops/ecbocp22.pdf.

Nan, Liangjin and Xue, Jinjun. "Estimation of China's Population and Labor Force, 1949-1999” (in Chinese). China Population Science, 2002, No. 4, pp. 1-16.

National Bureau of Statistics of China. China Statistical Yearbook. Beijing: China Statistics Press, 2005a, 2006, 2007a, and 2008.

National Bureau of Statistics of China. Comprehensive Statistical Data and Materials on 55 Years of New China. Beijing: China Statistics Press, 2005b.

National Bureau of Statistics of China. China Labour Statistical Yearbook. Beijing: China Statistics Press, 2007b.

National Bureau of Statistics of China. Historical Data on China's Gross Domestic Product Accounting, 1952-2004. Beijing: China Statistics Press, 2007c.

Nelson, Richard R. and Romer, Paul M. "Science, Economic Growth, and Public Policy.” Challenge, March-April 1996, 39(2), pp. 9-21.

Ofer, Gur. "Soviet Economic Growth: 1928-1985." Journal of Economic Literature, December 1987, 25(4), pp. 1767-833. 
Oliner, Stephen D.; Sichel, Daniel E. and Stiroh, Kevin J. "Explaining a Productive Decade." Brookings Papers on Economic Activity, 2007, 1, pp. 81-152.

People’s Daily (Beijing, China). “Green GDP System to Debut in 3-5 Years in China.” March 12, 2004.

Phelps, Edmund S. "The Boom and the Slump: A Causal Account of the 1990s/2000s and the 1920s/ 1930s." Journal of Policy Reform, March 2004, 7(1), pp. 3-19.

Prescott, Edward C. "Needed: A Theory of Total Factor Productivity.” International Economic Review, August 1998, 39(3), pp. 525-51.

Prescott, Edward C. "Richard T. Ely Lecture: Prosperity and Depression." American Economic Review, May 2002, 92(2), pp. 1-15.

Proietti, Tommaso; Musso, Alberto and Westermann, Thomas. "Estimating Potential Output and the Output Gap for the Euro Area: A Model-Based Production Function Approach.” Empirical Economics, July 2007, 33(1), pp. 85-113.

Reuters. “China’s Revised 2007 GDP Growth Moves It Past Germany.” January 15, 2009.

Romer, David. Advanced Macroeconomics. Third Edition. Boston: McGraw-Hill Irwin, 2006.

Schiff, Lenore. "Economic Intelligence: Is the Long Wave About To Turn Up?” Fortune, February 22, 1993, 127(4), p. 24.

Segerstrom, Paul S. "Endogenous Growth without Scale Effects." American Economic Review, December 1998, 88(5), pp. 1290-310.

Sterman, John D. "The Long Wave." Science, March 18, 1983, 219(4590), p. 1276.

Sterman, John D. "A Behavioral Model of the Economic Long Wave.” Journal of Economic Behavior and Organization, 1985, 6(1), pp. 17-53.

Sterman, John. "The Long Wave Decline and the Politics of Depression.” Bank Credit Analyst, 1992, 44(4), pp. 26-42.
Solow, Robert M. "Perspectives on Growth Theory." Journal of Economic Perspectives, Winter 1994, $8(1)$, pp. 45-54.

Stiglitz, Joseph. "The Roaring Nineties.” Atlantic Monthly, October 2002, 290(3), pp. 76-89.

Stiroh, Kevin J. "Is There a New Economy?” Challenge, July-August 1999, 42(4), pp. 82-101.

Vatter, Harold G. and Walker, John F. "Did the 1990s Inaugurate a New Economy?” Challenge, JanuaryFebruary 2001, 44(1), pp. 90-116.

Walsh, John. "Is R\&D the Key to the Productivity Problem?” Science, February 1981, 211(13), pp. 685-88.

Wen, Jiabao. "Report on the Work of the Government." Presented at the First Session of the 11th National People’s Congress, March 5, 2008.

World Bank. Expanding the Measure of Wealth: Indicators of Environmentally Sustainable Development. Washington, DC: Environment Department, World Bank, 1997.

World Bank. World Development Indicator CD-ROM. Washington, DC: World Bank, 2006 and 2008.

World Bank. China Quarterly Update. Washington, DC: World Bank, December 2008.

Xinhua. "Highlights of Chinese Premier Wen Jiabao's Government Work Report.” March 8, 2008, update.

Young, Alwyn. "The Tyranny of Numbers: Confronting the Statistical Realities of the East Asian Growth Experience.” Quarterly Journal of Economics, August 1995, 110(3), pp. 641-80.

Zheng, Jinghai. "On Chinese Productivity Studies.” Journal of Chinese Economic and Business Studies, May 2008, 6(2, Special Issue), pp. 109-19.

Zheng, Jinghai; Bigsten, Arne and Hu, Angang. "Can China's Growth Be Sustained: A Productivity Perspective?" World Development, April 2009, 37(4, Special Issue), pp. 874-88. 
Zheng, Jinghai and Hu, Angang. "An Empirical Analysis of Provincial Productivity in China (19792001)." Journal of Chinese Economic and Business Studies, 2006, 4(3), pp. 221-39.

\section{APPENDIX: DATA DESCRIPTION}

The main variables investigated in the study are aggregate output (GDP at a constant price), aggregate labor (the number of people employed), and capital stock (accumulated fixed capital investment at a constant price). For details of the treatment of data, see Zheng, Bigsten, and Hu (2009, appendix). Here we outline the data used in addition to those in that study.

\section{Capital Stock}

We have collected a series of capital stock, which is the accumulation of total social fixed asset investment since 1978. We use the price indices of gross fixed capital formation from Historical Data of China's Gross Domestic Product Accounting, 1952-2004 (NBSC, 2007c) to deflate investment data before 1990. For investment after 1990, we use the price indices of fixed asset investment from the China Statistical Yearbook (NBSC, 2005a, 2006a, 2007a, and 2008) See Figures A1 through A3 for time plots of the series and related measures.

\section{Labor}

The labor force data used are the economically active population data from Comprehensive Statistical Data and Materials on 55 Years of New China (NBSC, 2005b) and are extended to 2007 based on the growth rate for each year from the China Statistical Yearbook (NBSC, 2005a, 2006, 2007a, and 2008). Because of the inconsistency of official data before 1990, we use an adjusted series of labor force from Nan and Xue (2002) to update our pre-1990 data. The data on employment are from the China Labour Statistical Yearbook (NBSC, 2007b). We generate a new series of the data before 1990 based on the official unemployment (defined as the gap of economic active population and employment) and the labor force data from Nan and Xue (2002). (See Figures A4 to A6.)

\section{Human Capital}

To measure human capital, we use average years of schooling of Chinese laborers to adjust for labor quality improvement. Data for 1978-2005 are from Holz (2005) and include two series, one with and one without military service included. We use the former. "Labor" is defined as quality-adjusted laborers, that is, the number of employees multiplied by the average years of schooling. (See Figures A7 to A9.)

\section{Energy Consumption and Carbon Dioxide Emission}

Energy consumption data and its structure are from Comprehensive Statistical Data and Materials on 55 Years of New China (NBSC, 2005b), which provides consumption of fossil fuel (to estimate the carbon dioxide $\left[\mathrm{CO}_{2}\right]$ emissions) together with cement production data. $\mathrm{CO}_{2}$ emissions based on energy consumption is calculated according to the following formula: 


\section{Zheng, Hu, Bigsten}

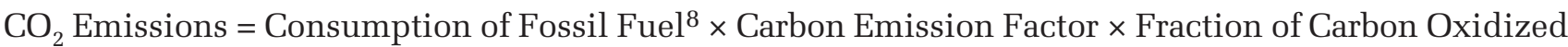
+ Production of Cement $\times$ Processing Emission Factor.

The fraction of carbon oxidized refers to the ratio of carbon oxidized to the quantity of $\mathrm{CO}_{2}$ emitted, which is a constant ratio 3.67 (44:12). The most important coefficient here is the carbon emission factor, which refers to the equivalent carbon emissions in the consumption of fossil fuel. We use the factor from the Energy Research Institute of China's National Development and Reform Committee, which is 0.67 per ton of coal-equivalent fuel. Further, the production of cement emits more $\mathrm{CO}_{2}$ than the consumption of fossil fuel because of the calcining of limestone, which on average creates 0.365 tons of $\mathrm{CO}_{2}$ per ton of cement produced (China Cement, 2007).

Figure A1

\section{Gross Capital Stock Growth}

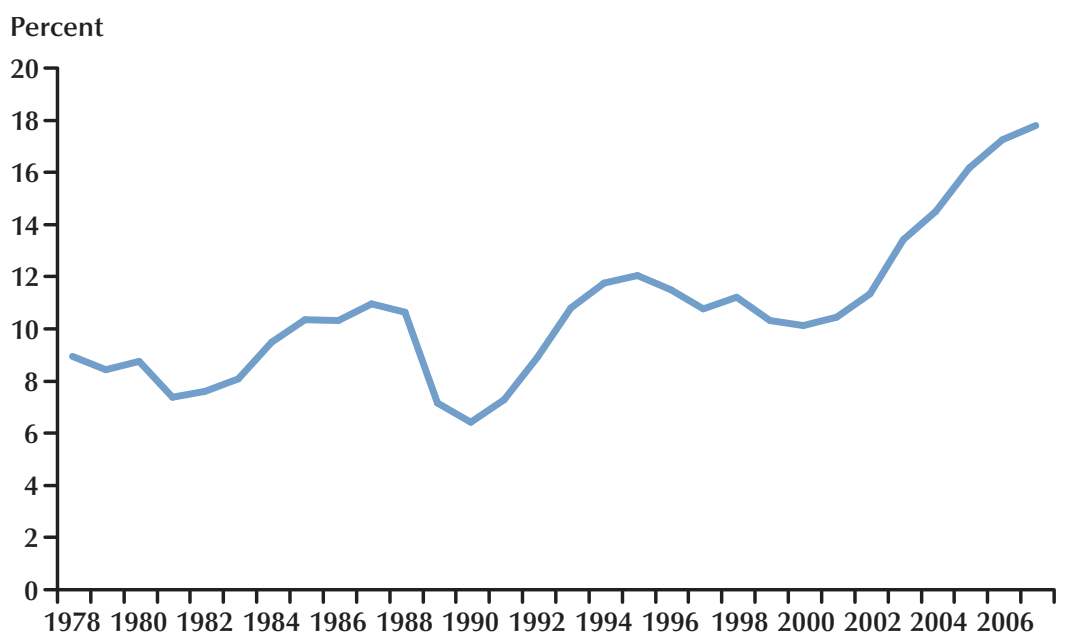

8 A more-accurate calculation would exclude the carbon sink. We use the approximate amount because of the limited availablity of data. 


\section{Figure A2}

\section{Gross Capital Stock and Its Components}

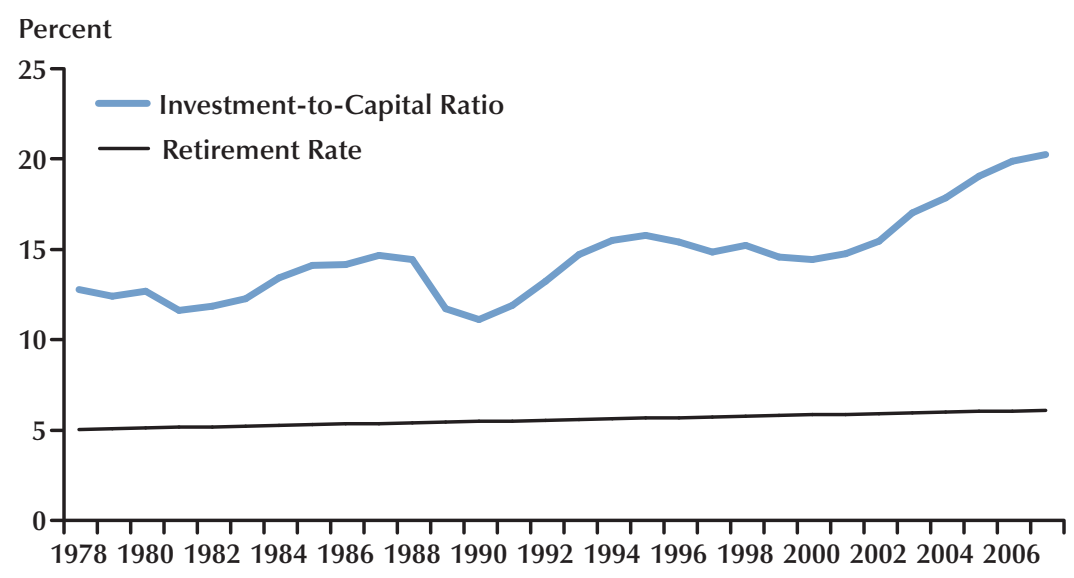

\section{Figure A3}

\section{Determinants of the Investment-to-Capital Ratio}

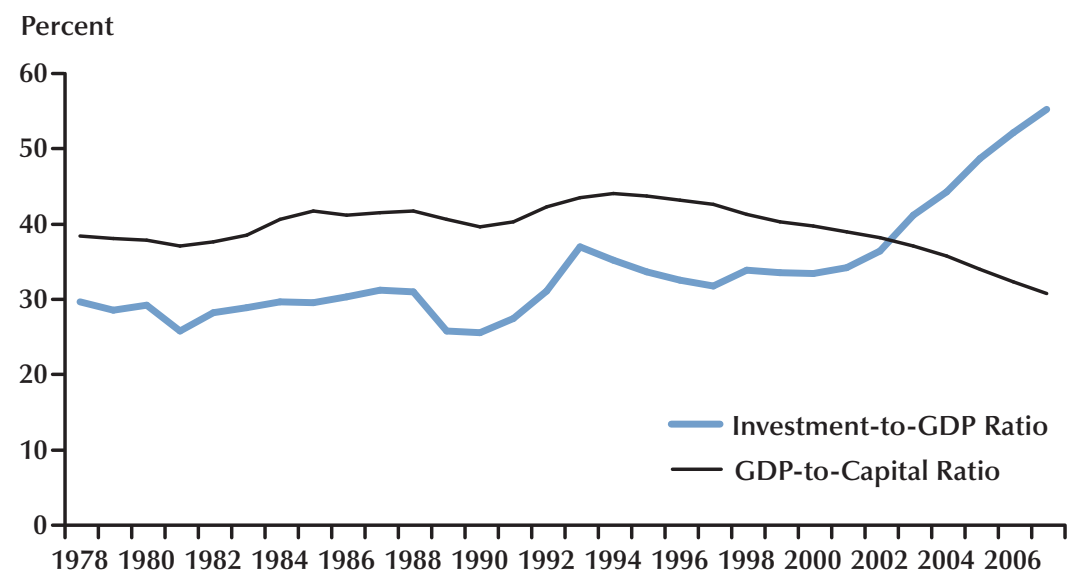


Figure A4

\section{Labor Force Growth}

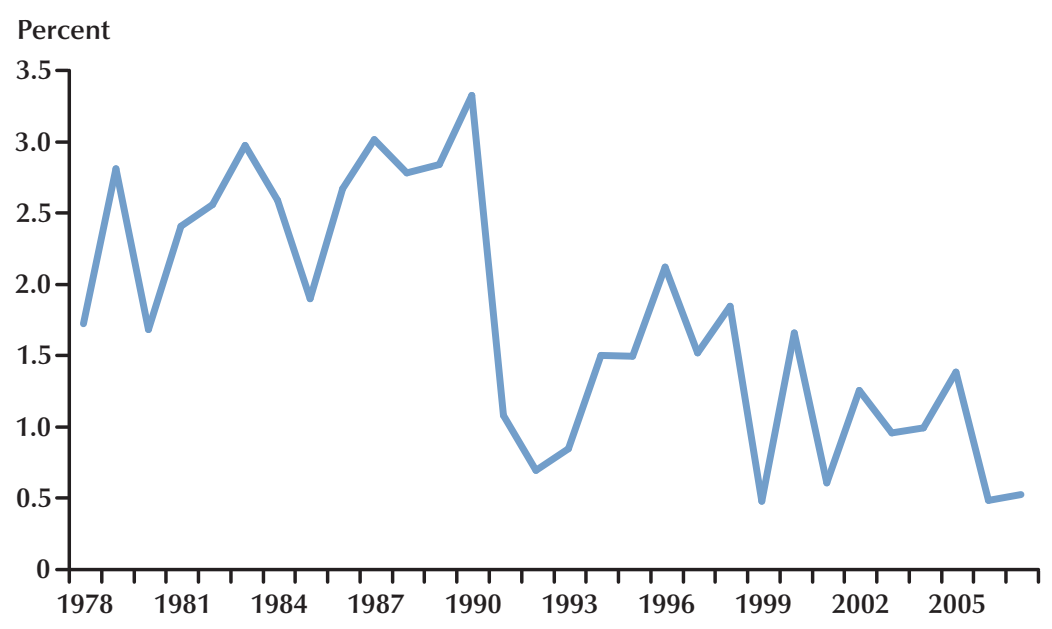

Figure A5

\section{Unemployment Rate}

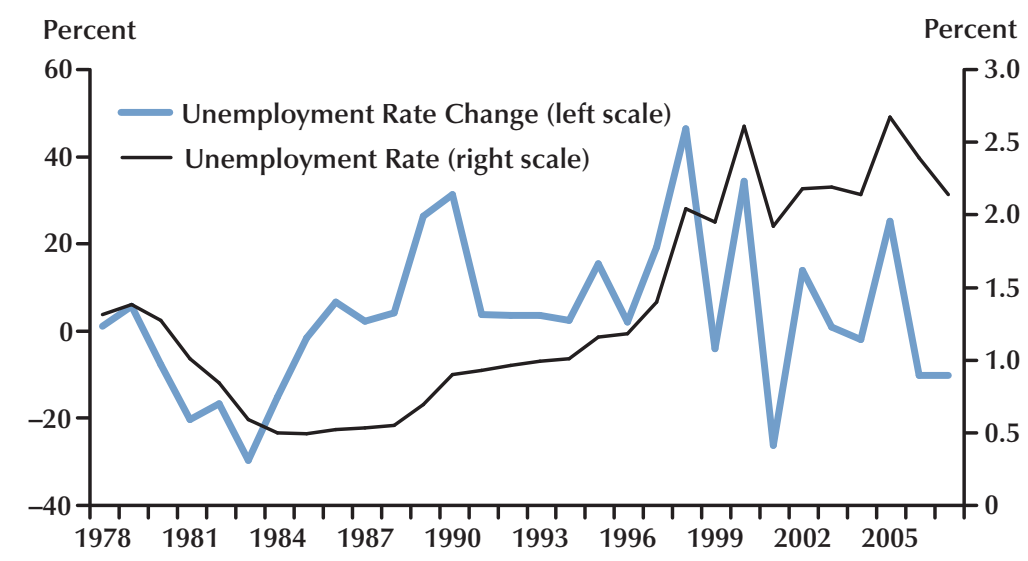




\section{Figure A6}

\section{Working-Age Population Growth}

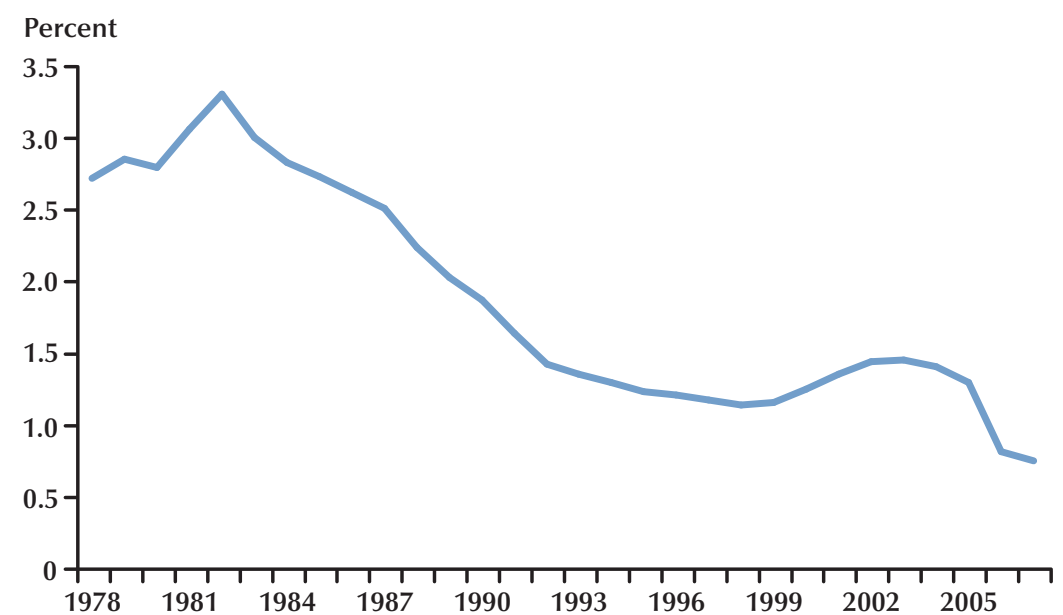

\section{Figure A7}

\section{Participation Rate}

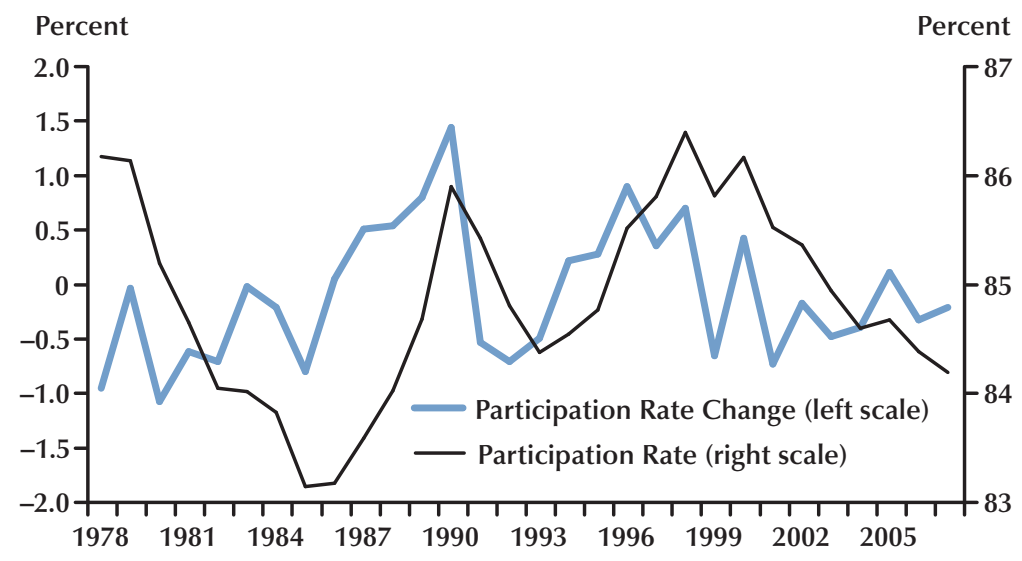


Figure A8

\section{Population Growth}

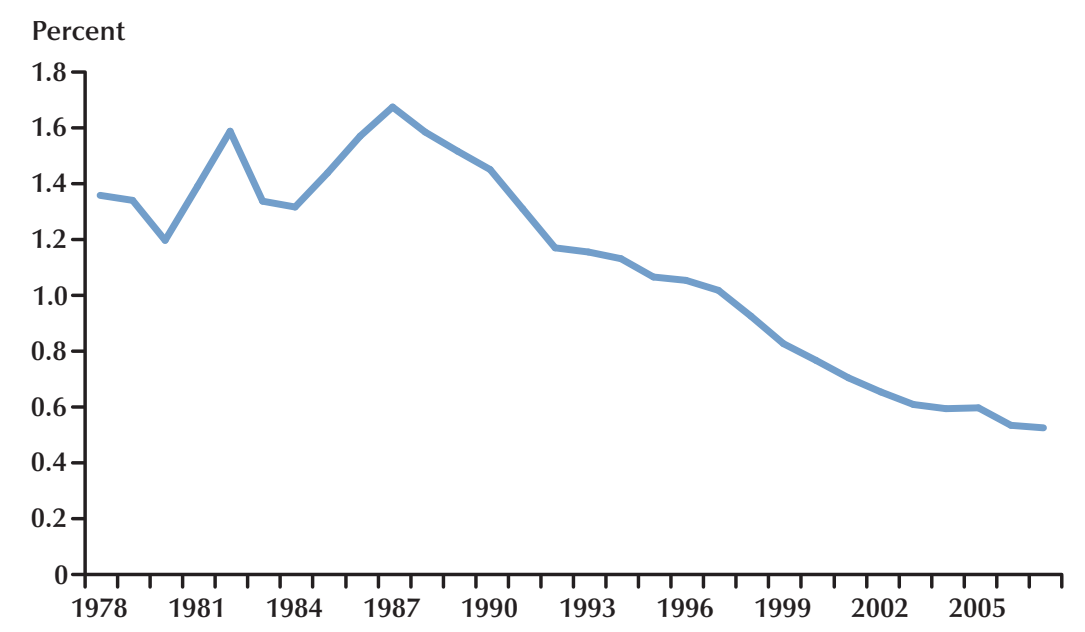

Figure A9

\section{Dependency Ratio}

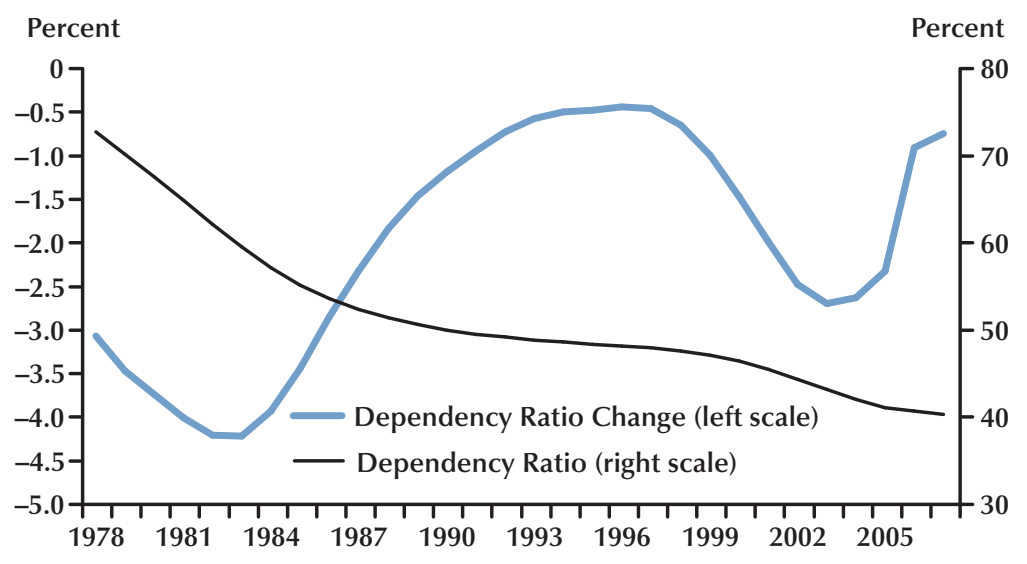

